\title{
Hydrologic and hydraulic modelling of the Nyl River floodplain Part 3: Applications to assess ecological impact
}

\author{
MT Kleynhans ${ }^{1 *}$, CS James ${ }^{1}$ and AL Birkhead ${ }^{2}$ \\ ${ }^{1}$ Centre for Water in the Environment, School of Civil \& Environmental Engineering, University of the Witwatersrand, \\ Johannesburg, South Africa \\ ${ }^{2}$ Streamflow Solutions cc, East London, South Africa
}

\begin{abstract}
The ecological functioning of the Nyl River floodplain in the Limpopo Province of South Africa depends on water supplied by catchments which are experiencing continuing water resource development. Hydrological and hydraulic models have been produced to assist in future planning by simulating the effects of developments on ecologically relevant flooding characteristics. The models are applied here to predict the impacts of different development scenarios on the areal extent of suitable habitat for a key species, the Wild Rice (Oryza longistaminata), which can be characterised in terms of the depth, duration and timing of flood events. The results show that historical developments in the contributing catchments have already significantly reduced the area suitable for Wild Rice growth, particularly in relatively dry years, and increased the likely dry period between flooding events. Dam construction on one of the tributaries would reduce the suitable area further in dry to average years and increase the inter-event dry period. Careful dam operation could ameliorate impacts in very dry years, however.
\end{abstract}

Keywords: Nyl River floodplain, Nylsvlei, Nylsvley Nature Reserve, wetland modelling, wetlands, environmental impact, ecohydraulics, hydroecology

\section{Introduction}

The Nyl River floodplain in the semi-arid Limpopo Province of South Africa is an internationally recognised conservation area, supporting a large proportion of the breeding population of inland water birds in Southern Africa (Tarboton, 1991), as well as a wide variety of mammals, reptiles, fish and insects (Tarboton, 1987). The ecological functioning of the floodplain is driven, in part, by seasonal floods, which occur during the summer season in three out of five years on average (Higgins et al., 1996). Water resource development in the Nyl catchment has altered the flooding regime (Havenga et al., 2007) which has affected the ecological functioning of the floodplain.

In 1996 the Department of Water Affairs and Forestry (DWAF) initiated a study of the hydrology and hydraulics of the floodplain to assess the potential ecological impacts of future water resource developments. A daily hydrological model set up by Pitman and Bailey (2004) was used to simulate the timing and volumes of flows delivered to the floodplain. Part 1 of this paper in 3 parts by Havenga et al. (2007) provides further details. The flows produced by the hydrological models were then transformed by one-dimensional hydraulic models into flooding (such as depth and extent of inundation). Part 2 by Birkhead et al. (2007) describes the one-dimensional hydraulic models.

This paper presents the application of the hydrological and hydraulic models to predict the potential impacts that land use, water resource development and the construction of dams can have on ecologically important flood conditions on the floodplain. Although the floodplain animals and plants all depend on the occurrence of water, the only known quantification of these

* To whom all correspondence should be addressed.

용 +2721 481-2400; fax: +27121 424 5588;

e-mail: martin.kleynhans@shands.co.za

Received 16 May 2006; accepted in revised form 21 November 2006. dependencies is for the vegetation, particularly the Wild Rice species Oryza longistaminata (Marneweck, 2003). This species was used as an indicator of ecological response to potential changes in depth, duration, timing and inundation frequency. The insights gained have value beyond just Oryza longistaminata requirements, however, because the vegetation is also an important contributor, directly and indirectly, to the requirements of mammals, fish and birds. For example, the distribution and diversity of water birds in the system are related to the physical structure of the vegetation (Marneweck, 1990). Further details of the scenario applications are provided by Kleynhans (2005).

\section{Modelling for Oryza longistaminata requirements}

The output requirements of the hydraulic modelling were specified to enable quantification of the habitat requirements of Wild Rice (Oryza longistaminata). Recent studies have shown that distinct vegetation communities can be recognised in relation to elevation on the floodplain (Higgins et al., 1996), and that plant species composition varies significantly with changes in elevation as small as $9 \mathrm{~cm}$ (Coetzee and Rogers, 1991). It has been shown that Wild Rice grows best within a fairly well-defined range of flow depths (between 0.1 and $0.5 \mathrm{~m}$ (Marneweck, 2003)). These findings suggest that water depth during flooding is an important determinant of vegetation community structure. The duration of flooding, and its timing is also important: Wild Rice needs at least 25 days of continuous inundation to flower and set seed if the flood occurs in January or February, but longer if inundation occurs earlier or later in the rainy season. Wild Rice is adapted to the seasonal and periodic nature of flooding and goes through its entire ontogenetic lifecycle whether inundation takes place or not. Its life-cycle response allows it to cope with the variability in timing of inundation common in semi-arid areas. If there is no inundation, the plant 
relies on stored resources, energy and water in the rhizome to carry out this life cycle (Marneweck, 2003). However, according to Marneweck (2003), the Wild Rice becomes severely stressed after about three years of continuous drought, when the population becomes fragmented, old rhizomes become moribund, and species dominance on the floodplain declines. The temporal distribution of suitable inundation conditions is therefore an additional determinant of Wild Rice health.

The area of floodplain that is suitable for Wild Rice is therefore that which is inundated to the appropriate depth, for the appropriate duration, at the appropriate time of season, and with sufficient frequency. Changes in these descriptors (depth, duration, timing and frequency) can be estimated from hydrological (Havenga et al., 2007) and hydraulic models (Birkhead et al., 2007).

\section{Catchment development scenario simulations}

Four scenario applications of the hydrological and hydraulic models are presented here for illustration purposes. This was done to demonstrate the potential ecological application of the models and to assess the potential impacts of flow changes on the floodplain. The four scenarios were:

1. Pre-development hydrological conditions (as a baseline).

2. Actual historical conditions in all catchments with growth in developments through the period, including dams, irrigation and afforestation.

3. Historical conditions as for Scenario 2, but including a dam on the Olifantspruit with a constant environmental release of $30 \mathrm{l} / \mathrm{s}$. (This dam was proposed in 1993 (TPGP, 1993) for urban water supply, but was never built due to inadequate understanding of its environmental impact on the floodplain (Havenga et al., 2007)).

4. As for Scenario 3, but with the dam capacity large enough never to allow outflows, to investigate the extreme case of this dam development.

Each of these scenarios was simulated for the 331-month period from 1 October 1973 to 1 May 2001 to quantify the impacts within the Nylsvley Nature Reserve reach of the floodplain (Birkhead et al., 2007).

\section{Frequency of floodplain area inundation}

The effects that the different scenarios would have on the frequency of occurrence of inundation were investigated through the construction of inundation area-frequency curves (similar to flow-duration curves). The scenario conditions were represented by appropriate parameter values in the hydrological model input, to produce development-affected floodplain inflows, which were then input to the hydraulic models. Areas inundated within the Nylsvley Nature Reserve were determined on a daily basis using the hydraulic model results and the inflow-inundated area relationship developed by Birkhead et al. (2007). The number of days in the record period (out of the total of 10 075) for which various areas were inundated was calculated for each case and plotted in Fig. 1.

The occurrence of inundation areas exceeded up to $2 \mathrm{~km}^{2}$ decreases rapidly, reflecting the seasonal variability of the floodplain inundation.

The effects of the different scenario conditions are clear for small inundation areas, but less so for larger areas. It is more meaningful to compare impacts to some baseline condition. Figure 2 therefore represents the percentage change in the number

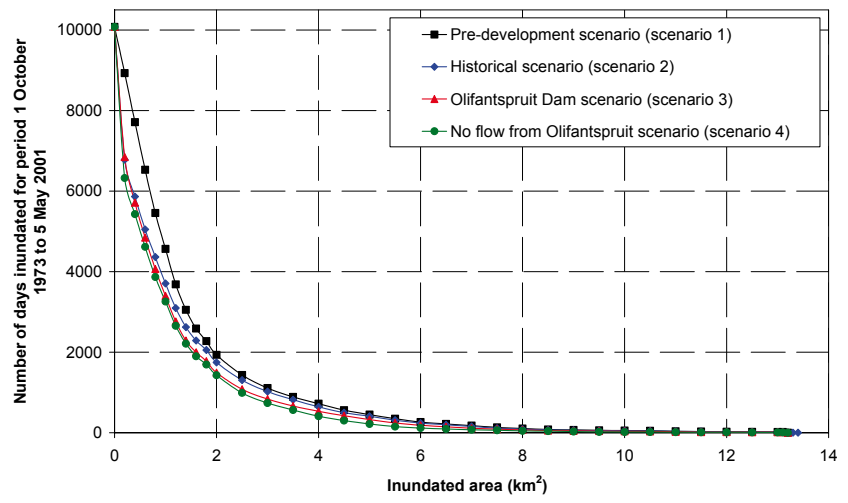

Figure 1

Frequency of occurrence of inundation areas exceeded, in the Nylsvley Nature Reserve reach for each catchment development scenario

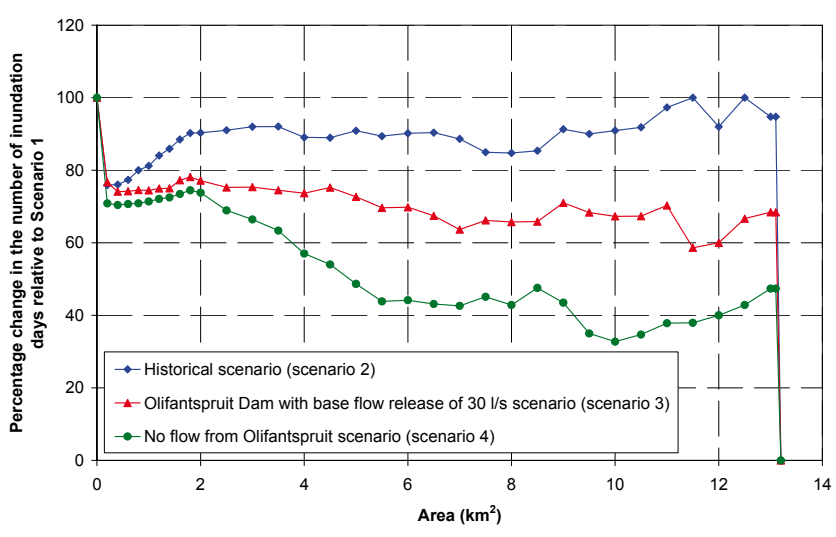

Figure 2

Frequency of occurrence of inundation areas exceeded in the Nylsvley Nature Reserve reach compared to the predevelopment hydrology scenario (Scenario 1)

of inundation days for Scenarios 2, 3 and 4 relative to Scenario 1. While Fig. 3 represents the percentage change in the number of inundation days for Scenarios 3 and 4 relative to Scenario 2. The comparison in Fig. 2 shows that historical development has decreased the occurrence of inundation under pre-development hydrological conditions by up to $24 \%$ for areas $<2.5 \mathrm{~km}^{2}$ and by approximately $10 \%$ for inundation areas $>2.5 \mathrm{~km}^{2}$. There is little difference in the occurrence of inundation between the pre-development and historically developed conditions for areas greater than about $11.5 \mathrm{~km}^{2}$, probably because inundation of relatively large areas occurs only in particularly wet periods when catchments are saturated and development demands are small. The Olifantspruit Dam (Scenario 3) shows a greater decrease in the occurrence of inundation areas than the historical catchment (Scenario 2), especially for inundation areas $>2.5 \mathrm{~km}^{2}$. Scenario 4 reflects an even greater change potential.

Pre-development hydrological conditions cannot be regained, and it is more realistic to assess the potential impacts of the dams by comparison to the historically developed condition (Scenario 2). Compared to the historical scenario the construction and operation of the Olifantspruit Dam as proposed in 1993 (Scenario 3) would have caused significant reduction in the frequency of occurrence of inundated areas on the floodplain, this effect increasing with increasing inundation areas exceeded (Fig. 3). Again, the larger dam (Scenario 4) would have increased 


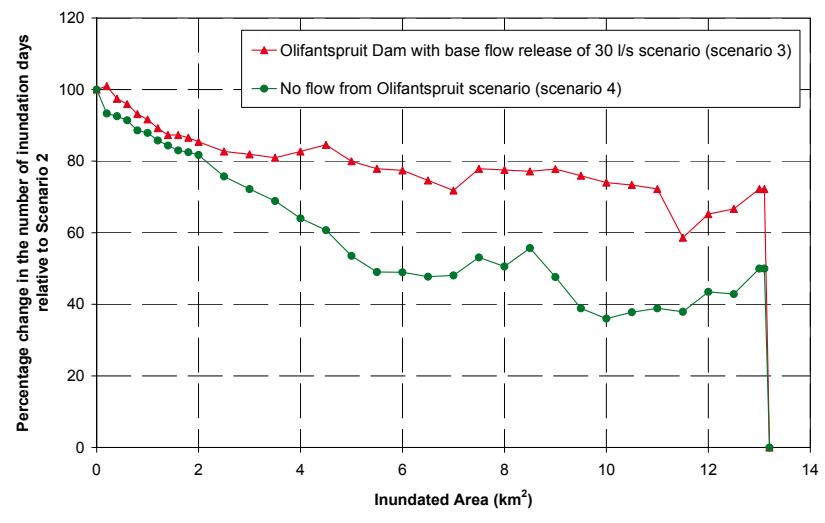

Figure 3

Frequency of occurrence of inundation areas exceeded in the Nylsvley Nature Reserve reach compared to the historical scenario (Scenario 2)

the severity of the impact; this scenario also demonstrates the important contribution of the Olifantspruit to inundation of the floodplain.

\section{Optimal areas for Wild Rice growth}

Inundated area is an insufficient measure of Wild Rice habitat because of its requirements for a particular range of inundation depths (between 0.1 and $0.5 \mathrm{~m}$ ) and inundation duration ( 25 continuous days) for optimum growth. The hydraulic models can be applied to identify inundated areas that satisfy these conditions simultaneously, and hence evaluate the impacts of the scenarios on habitat suitable for Wild Rice.

The RiverCAD floodplain mapping module was used to find inundated areas in the required depth range for different inflows, and the inflow-inundation area relationship presented in Fig. 4 was developed. This shows that an optimum inflow exists, above which the inundated area with the desired depth range decreases. This characteristic is a reflection of the valley shape of the Nylsvley floodplain - inflows above about $20 \mathrm{~m}^{3} / \mathrm{s}$ increase the area inundated, but the incremental addition has a depth of below $0.1 \mathrm{~m}$, while the raised water level increases the depth of a larger incremental area to more than $0.5 \mathrm{~m}$. Figure 4 shows that there is potentially about $6.5 \mathrm{~km}^{2}$ of suitable Wild Rice habitat on the floodplain within the Nylsvley Nature Reserve reach. Optimal conditions for Wild Rice require the ideal depth range to persist for 25 continuous days, however, and inflows of $20 \mathrm{~m}^{3} / \mathrm{s}$ never persisted for long enough during the period of analysis (October 1973 to May 2001) for these to be attained. The largest area to satisfy both the flow depth and duration conditions during this period was $4.3 \mathrm{~km}^{2}$ in 1995/96.

The annual maximum areas inundated within the Nylsvley Nature Reserve reach of the floodplain that conformed to the

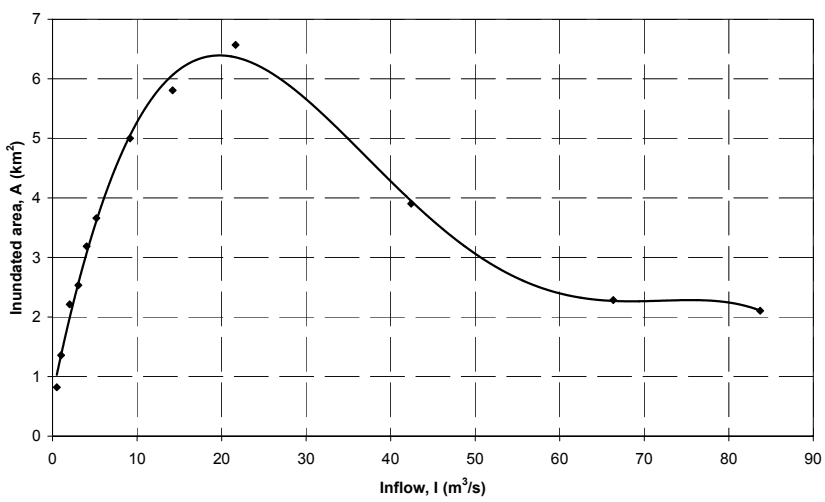

Figure 4

Inflow, I $\left(\mathrm{m}^{3} / \mathrm{s}\right)$ vs. inundated area with depth between $0.1 \mathrm{~m}$ and $0.5 \mathrm{~m}, A,\left(\mathrm{~km}^{2}\right)$ regression for the Nylvley Nature Reserve reach

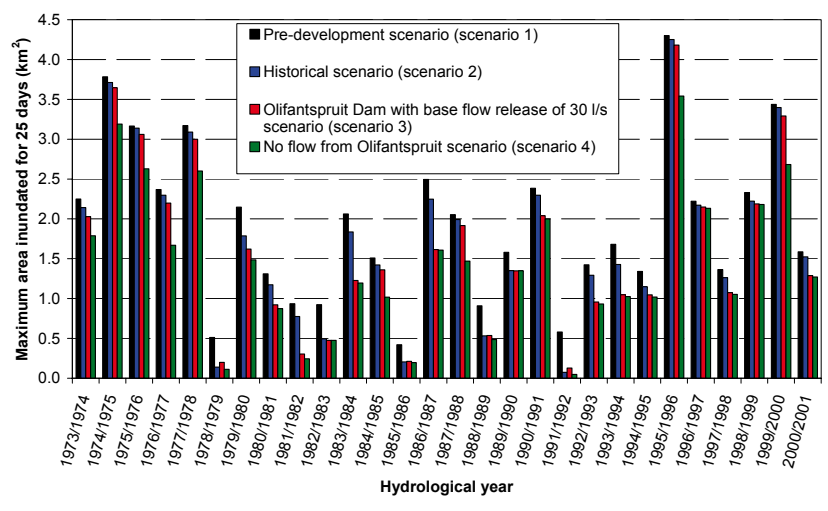

Figure 5

Inundation areas $\left(\mathrm{km}^{2}\right)$ suitable for the optimum growth of Wild Rice, for each year and scenario for the Nylsvley Nature Reserve reach

duration and depth requirements of the Wild Rice are shown for the different scenario conditions in Fig. 5. The relative impacts are different in different years, depending on the degree of flooding. Impacts on suitable habitat areas relative to the pre-development (Scenario 1) and historically developed (Scenario 2) conditions are presented in Table 1 for typical wet (1995/96), dry (1991/92) and intermediate $(1981 / 82)$ years, as well as the overall average impact. The results presented in Fig. 5 show that historical catchment developments, such as farm and water supply dams and irrigation schemes, have already had a significant impact on suitable Wild Rice habitat in the Nylsvley Nature Reserve reach. This is especially so during dry years such as 1978/1979 and 1991/1992 when suitable inundated areas were reduced by $73 \%$ and $87 \%$ respectively. Historical catchment developments

\begin{tabular}{|c|c|c|c|c|c|c|c|c|c|}
\hline \multicolumn{10}{|c|}{$\begin{array}{c}\text { TABLE } 1 \\
\text { Inundation areas }\left(\mathrm{km}^{2}\right) \text { in the Nylsvley Nature Reserve reach suitable for the optimum } \\
\text { growth of wild rice and the proportional reduction in these areas compared to Scenarios } \\
1 \text { and } 2\end{array}$} \\
\hline & \multirow{2}{*}{$\begin{array}{c}\text { Scenario } 1 \\
\mathrm{~km}^{2} \\
\end{array}$} & \multicolumn{2}{|c|}{ Scenario 2} & \multicolumn{3}{|c|}{ Scenario 3} & \multicolumn{3}{|c|}{ Scenario 4} \\
\hline & & $\mathbf{k m}^{2}$ & $\%$ of 1 & $\mathbf{k m}^{2}$ & $\%$ of 1 & $\% \mathrm{c}$ & $\mathrm{km}^{2}$ & $\%$ of 1 & $\%$ of 2 \\
\hline Average & 1 & 1.76 & $91 \%$ & 1.61 & $33 \%$ & 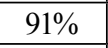 & & $74 \%$ & \\
\hline 1981// & & 0.77 & $83 \%$ & 0.30 & 20 & & & $26 \%$ & $31 \%$ \\
\hline $1991 /$ & & 0.07 & $13 \%$ & 0.13 & 0 & 17 & & $8 \%$ & $67 \%$ \\
\hline 1995/96 (Wet) & 4.30 & 4.25 & $99 \%$ & 4.18 & $97 \%$ & $98 \%$ & 3.54 & $82 \%$ & $83 \%$ \\
\hline
\end{tabular}




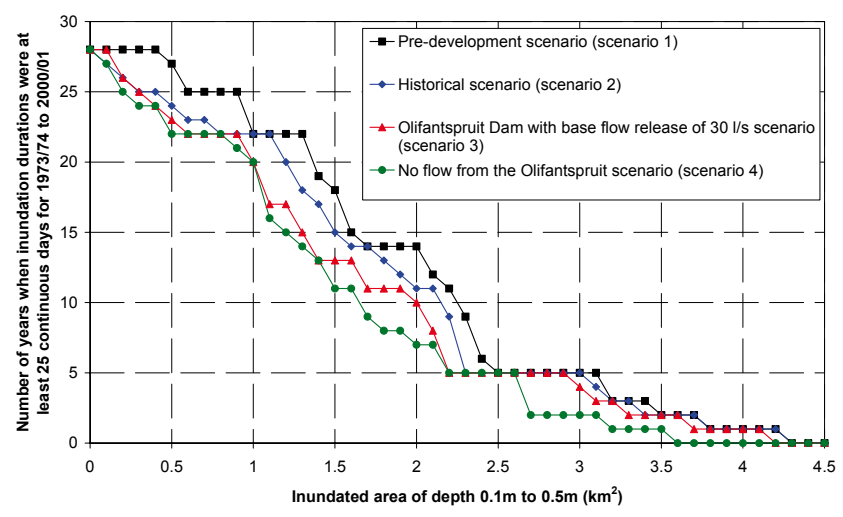

Figure 6

Number of years in which different inundation areas of depths between $0.1 \mathrm{~m}$ and $0.5 \mathrm{~m}$ and of at least 25 continuous days duration were exceeded for the different scenarios in the Nylsvley Nature Reserve reach

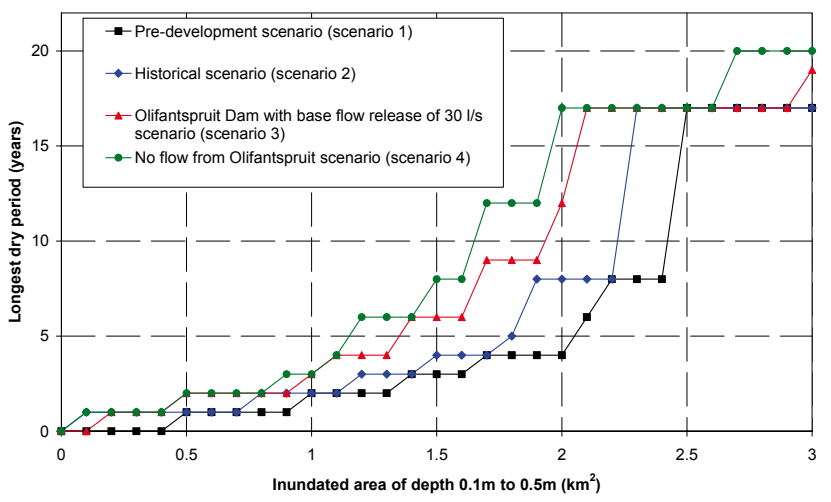

Figure 7

Maximum durations of suitable conditions for Wild Rice not being met for different inundation areas

had a far smaller impact on suitable habitat during wet years when the dams were already full. In 1995/1996, for example, suitable inundated areas were reduced by just $1 \%$ in Scenario 2 compared with Scenario 1. The Olifantspruit Dam (Scenario 3) would have reduced suitable inundated areas even further in most years, but not in certain dry years, when the constant environmental base flow release would have increased suitable inundation areas on the floodplain compared with Scenario 2. For example, in the drought year 1991/1992 the suitable inundation area was increased by $75 \%$ by this base flow release over the inundation area for Scenario 2. This demonstrates that although the construction of dams in the catchments would have a negative effect on suitable inundation areas in most years, the impact could be mitigated with careful operation, and the dam could even be used to increase the area in crucial dry years, hence reducing the impact of other catchment developments. The dam had the greatest impact on suitable inundation area in 1981/1982 when it was reduced by $61 \%$ compared with Scenario 2 . The dam was nearly empty before this flood event. The importance of the Olifantspruit contribution to maintaining suitable inundation areas was tested using Scenario 4, where all flow was absorbed by an infinitely large dam. The relative contribution of the Olifantspruit was found to be greatest during dry years; for example the extreme case during the record period occurred in 1981/1982 when suitable inundation area was reduced by $69 \%$ in Scenario 4 compared with Scenario 2.

\section{Frequency of occurrence of areas suitable for Wild Rice growth}

The hydraulic model output can be interrogated to assess the frequency of exceedance of the maximum annual inundation areas suitable for Wild Rice growth. The frequencies of inundation of the areas determined for the different scenarios (Fig. 5) are presented in Fig. 6. This shows, for example, that an area of 2 $\mathrm{km}^{2}$ would have been suitably inundated in 14 out of 28 years under pre-development hydrological (Scenario 1) conditions, in 11 years under historically developed (Scenario 2) conditions, in 10 years with the proposed dam (Scenario 3 ) and in only 7 years with the enlarged dam (Scenario 4). The impact on inundation frequency of suitable areas of the historical catchment developments (Scenario 2) compared with pre-development hydrological conditions (Scenario 1) is greatest for inundation areas less than $2.5 \mathrm{~km}^{2}$ (corresponding to relatively dry years), where the reduction in frequency was as much as $56 \%$ for $2.3 \mathrm{~km}^{2}$. The reduction in inundation frequency was less for inundation areas greater than $2.5 \mathrm{~km}^{2}$ because inundation of these areas would have occurred during wet years when dams were already full before the largest flood events occurred. The Olifantspruit Dam (Scenario 3) would also have had the greatest impact on the frequency of annual maximum suitable inundation areas for relatively small areas in the relatively dry years, with a maximum reduction in frequency of $56 \%$ for a suitable inundation area of $2.2 \mathrm{~km}^{2}$ compared with Scenario 2. The enlarged dam (Scenario 4) would have exacerbated the impact by further reducing the frequencies for relatively small areas (dry years) and also effecting significant reductions for the larger areas (wet years), leading to no occurrence of inundation for areas greater than $3.6 \mathrm{~km}^{2}$, compared with $4.3 \mathrm{~km}^{2}$ under pre-development (Scenario 1) and historically developed (Scenario 2) conditions.

Frequency of inundation provides an indication of how often suitable conditions are available, but it does not account for the effect of climate variability. This is particularly important because extended durations of dry floodplain conditions result in reductions in the Wild Rice population (Marneweck, 2003). A more realistic measure of the impact of temporally reduced inundation can be obtained by interrogating the model output to quantify the durations of dry periods between inundation events caused by developments. For example, the maximum dry period durations for different areas under the different scenarios are presented in Fig. 7. This shows that historical developments (Scenario 2) affected the dry conditions experienced by the vegetation generally only for areas up to about $2.5 \mathrm{~km}^{2}$. The Olifantspruit Dam (Scenario 3) would have also increased the longest dry period compared to the pre-development and historical scenarios up to about $2.5 \mathrm{~km}^{2}$, although the enlarged dam (Scenario 4) would have increased the longest dry period for most inundated areas. If 3 years is accepted as the critical dry duration between successive inundation events (as suggested by Marneweck (2003)) then only about $1.4 \mathrm{~km}^{2}$ of the floodplain in the Nylsvley Nature Reserve reach provides ideal habitat for the Wild Rice, compared to about $1.6 \mathrm{~km}^{2}$ for pre-development hydrological conditions (Scenario 1). The proposed and larger dams on the Olifantspruit would, however, reduce the ideal habitat area to about $1.0 \mathrm{~km}^{2}$.

\section{Conclusions}

Daily hydrological modelling and one-dimensional hydraulic modelling can simulate the impacts of catchment developments on the hydraulic conditions in the Nyl River floodplain with 
sufficient resolution for meaningful ecological interpretations to be made. Although Wild Rice has been used here as an indicator of ecological impact, similar interpretations could be made for other biotic components if their responses to changes in the hydraulic descriptors of depth, duration, timing and frequency of inundation were known.

Suitable habitat for growth of Wild Rice is defined primarily by areal extent, depth of inundation (between 0.1 and $0.5 \mathrm{~m}$ ), duration of inundation (a minimum of 25 continuous days) and the temporal distribution of inundation events (intra-seasonal timing and ideally with no longer than 3 years between satisfactory inundations).

The historical land use and water resource developments in the catchments supplying water to the Nyl River floodplain have already impacted on these habitat descriptors, significantly reducing the suitable area in the crucial dry years and increasing the dry period between inundations for most areas of inundation up to about $2.5 \mathrm{~km}^{2}$.

New dams in the contributing catchments would have a significant further impact on the Wild Rice habitat, decreasing suitable inundated areas in average years and increasing the inter-event dry period for most areas of inundation. Carefully controlled environmental releases could have an ameliorative effect in dry years, however.

\section{Acknowledgements}

The model development was undertaken under contract for the Department of Water Affairs and Forestry by Stewart Scott International (hydrological models) and the Centre for Water in the Environment at the University of the Witwatersrand and Streamflow Solutions (hydraulic models). The model applications and some hydraulic modelling were carried out by the first author towards his M.Sc.(Eng.) degree, supported by the National Research Foundation. Any opinion, findings and conclusions or recommendations expressed are those of the authors and therefore the NRF does not accept any liability in regard thereto.

\section{References}

BIRKHEAD AL, JAMES CS and KLEYNHANS MT (2007) Hydrological and hydraulic modelling of the Nyl River floodplain. Part 2: Modelling hydraulic behaviour. Water SA 33 (1) 9-20.

COETZEE MS and ROGERS KH (1991) Environmental correlates of plant species distribution on the Nyl River floodplain, South Africa. S. Afr. J. Aquat. Sci. 17 44-50.

HAVENGA CFB, PITMAN WV and BAILEY AK (2007) Hydrological and hydraulic modelling of the Nyl River floodplain. Part 1: Background and hydrological modelling. Water SA 33 (1) 1-8.

HIGGINS SI, COETZEE MAS, MARNEWECK GC and ROGERS KH (1996) The Nyl River floodplain, South Africa, as a functional unit of the landscape: A review of current information. Afr. J. Ecol. 34 131-145.

KLEYNHANS MT (2005) Hydraulic and Hydrological Modelling of the Nyl River Floodplain for Environmental Impact Assessment. Unpublished M.Sc. (Eng.) Dissertation, University of the Witwatersrand, Johannesburg, South Africa.

MARNEWECK GC (1990) Effects of Different Drying Regimes on the Species Composition of a Savannah Wetland. Unpublished Honours Report, University of the Witwatersrand, Johannesburg.

MARNEWECK GC (2003) Personal communication. Wetland Consulting Services, Pretoria.

PITMAN WV and BAILEY AK (2004) The Hydrologic and Hydraulic Study of the Behaviour of the Nyl River Floodplain - Hydrological Model Calibration. DWAF Report No. P WMA 01/A61/00/0403, Department of Water Affairs and Forestry, Pretoria, South Africa.

TARBOTON WR (1987) The Nyl Floodplain, Fauna and Flora. Vol. 45 (Special issue devoted to Nylsvlei) Transvaal Nature Conservation Division, Pretoria.

TARBOTON WR (1991) Flooding and the Avifauna of the Nyl Floodplain. Referaat aan die Nylstroom Beraad, Sessie 2.

TPGP (THERON PRINSLOO GRIMSEHL \& PULLEN Ing.) (1993) Aanvulling van die Watervoorsiening aan Nylstroom: Verslag oor die Evaluering van Alternatiewe Nuwe Waterbronne. Stadsraad van Nylstroom. Verslag No. 90H51/1. January 1993. 
Available on website http://www.wrc.org.za ISSN 0378-4738 = Water SA Vol. 33 No. 1 January 2007 ISSN 1816-7950 = Water SA (on-line) 